\title{
Dietary marine algae and its influence on tissue gene network expression during milk fat depression in dairy ewes
}

\author{
E. Bichi, ${ }^{\text {ab }}$ P. Frutos, ${ }^{a}$ P. G. Toral, ${ }^{a}$ D. Keisler, ${ }^{\text {c }}$ G. Hervás, ${ }^{a}$ and J. J. Loor $^{b^{*}}$
}

${ }^{a}$ Instituto de Ganadería de Montaña (CSIC-ULE), Finca Marzanas s/n. 24346 Grulleros, León, Spain

${ }^{b}$ Mammalian NutriPhysioGenomics, Department of Animal Sciences, and Division of Nutritional Sciences, University of Illinois, Urbana 61801, USA

${ }^{c}$ Department of Animal Science, University of Missouri, Columbia, MO 65211, USA

"Corresponding author:

J. J. Loor, Department of Animal Sciences and Division of Nutritional Sciences, University of Illinois, Urbana 61801, USA.

Telephone number: 1-217-244-5957

E-mail: jloor@illinois.edu 


\section{Abbreviations}

MA, marine algae; LCFA, long chain fatty acids; MFD, milk fat depression; SO, sunflower oil; SOMA, sunflower oil marine algae; TAG, triglycerides; GH, Growth Hormone; CLA, conjugated linoleic acid. 


\section{ABSTRACT}

Supplementation of a linoleic acid-rich diet with marine algae reduces milk fat content while impacting milk fatty acid profile in dairy sheep. Unlike other ruminant species, in ovine there are limited data on the molecular mechanisms that may regulate adipose, liver, and mammary responses to dietary marine lipids. This study was conducted to investigate changes in mRNA expression and relative mRNA abundance of key enzymes involved in lipid metabolism in mammary, subcutaneous adipose and liver tissue in response to long-term milk fat depression induced by marine algae. Eleven Assaf ewes were randomly assigned to 2 experimental diets consisting of a TMR based on alfalfa hay and concentrate (40:60) supplemented with $25 \mathrm{~g}$ of sunflower oil/kg DM plus 0 (SO; control diet) or $8 \mathrm{~g}$ of marine algae/kg of DM (SOMA diet) for 54 d. Quantitative reverse transcription-PCR was used to study expression of target genes in tissues harvested at slaughter at the end of the feeding period (54 d). There was no effect of SOMA on mammary and adipose tissue expression of genes encoding proteins required for fatty acid uptake and activation (ACSS2, $L P L)$, intracellular fatty acid transport (FABP3, FABP4), de novo fatty acid synthesis (ACACA, FASN), esterification (DGAT1, DGAT2, LPIN1), desaturation (SCD), elongation (ELOVL6), transcriptional regulation (INSIG1, MED1, PPARG, RXRA, SCAP, SREBF1, THRSP) and lipid droplet formation (ADFP, BTN1A1, XDH). Abundance of PPARG $(0.04 \%)$ and INSIG1 $(2.22 \%)$ in mammary tissue was markedly greater than that of SREBF1 $(0.002 \%)$, suggesting that they may play a more important role in milk fat synthesis regulation. Addition of marine algae did not affect the expression of ß-oxidation- and lipoprotein-related genes (ACOX1, APOB, CPT1A, PPARA, RXRA) in hepatic tissue. However, feeding SOMA upregulated hepatic HMGCS2, which controls ketogenesis. Concentration of plasma $\beta$ hydroxybutyrate, NEFA, glucose, triacylglycerol, growth hormone, insulin-like growth factor 1, 
insulin, and leptin was not different between groups at d 54. Taken together with the milk fat responses and previous data from bovine fed similar diets, results suggest that transcriptional control mechanisms regulating fat synthesis in mammary secretory tissue were likely established during earlier stages of the feeding period.

Keywords: marine lipids, gene expression, lipid metabolism, sheep 


\section{INTRODUCTION}

Inclusion of marine lipids in the diet of dairy sheep represents an effective nutritional strategy for altering milk fat composition (Papadopoulos et al., 2002; Reynolds et al., 2006; Capper et al., 2007). However, dietary marine algae (MA) have recently been associated with milk fat depression (MFD) in dairy ewes (Toral et al., 2010a; Bichi et al., 2013). Milk fat synthesis is known to involve the coordinated expression of several transcription regulators and their target genes (Bionaz and Loor, 2008). The role of altered lipogenic gene expression has been examined in lactating dairy cows fed a MFD diet (Piperova et al., 2000; Ahnadi et al., 2002; Harvatine and Bauman, 2006), and the transcriptomic adaptations outlined not only in mammary (Invernizzi et al., 2010) but also in adipose tissue (Thering et al., 2009).

Some long-chain fatty acids (LCFA) including 16:0, 18:0, trans-10 18:1, and trans-10, cis-12 18:2 alter bovine mammary cell lipogenic gene networks and in turn lipid droplet synthesis (Kadegowda et al., 2009). In particular, the trans-10 LCFA intermediates arising from ruminal metabolism of dietary unsaturated FA (Bauman et al., 2011) are potent inhibitors of lipogenesis via their negative effect on transcriptional control mechanisms regulating target genes (Kadegowda et al., 2009).

Data on the nutritional regulation of expression of lipogenic enzymes in small ruminants are limited (Agazzi et al., 2010; Shingfield et al., 2013; Hussein et al., 2013). Previous studies with goats evaluated lipogenic gene expression in adipose and mammary tissue in response to dietary vegetable and fish oil (Bernard et al., 2009a,b; Li et al., 2012; Toral et al., 2013) but direct comparisons between the sheep and the goat have identified species-specific differences in mRNA levels of mammary lipogenic genes (Tsiplakou et al., 2009). Furthermore, the goat appears to be less responsive to MFD than the ewe (Bernard et al., 2012; Shingfield et al., 2013). 
In lactating ewes, exogenous trans-10, cis-12 18:2 induced MFD (Lock et al., 2006; Sinclair et al., 2010; Oliveira et al., 2012; Hussein et al., 2013), but this isomer does not seem to play a relevant role in diet-induced MFD (Toral et al., 2010a,b; Bichi et al., 2013). To our knowledge, there is only limited information about the molecular adaptations in ovine tissues in response to diets that induce MFD (Hussein et al., 2013).

The objective of this study was to use adipose, liver, and mammary tissue from sheep fed a linoleic acid-rich TMR supplemented with MA that resulted in MFD (Bichi et al., 2013) to evaluate mRNA expression of transcription regulators and target genes to better understand the role of transcriptional mechanisms in the long-term nutritional regulation of diet-induced MFD.

\section{MATERIALS AND METHODS}

\subsection{Animals, Experimental Diets and Management}

All experimental procedures were performed in accordance with the Spanish Royal Decree $1201 / 2005$ for the protection of animals used for experimental and other scientific purposes. Details of the experimental procedures have been described previously (Bichi et al., 2013). Briefly, eleven fat-tailed Assaf ewes $(82.4 \pm 3.26 \mathrm{~kg} \mathrm{BW})$ in mid-lactation $(84 \pm 2.3 \mathrm{DIM}$ at the beginning of the experiment) were randomly assigned to two experimental diets consisting of a TMR based on alfalfa hay and a concentrate (40:60) supplemented with $25 \mathrm{~g}$ of sunflower oil (Carrefour S.A., Madrid, Spain)/kg of DM plus 0 (SO; control diet, $\mathrm{n}=5$ ) or $8 \mathrm{~g}$ of marine algae (DHA Gold Animal Feed Ingredient, Martek Biosciences Corp., Columbia, MD)/kg of DM (SOMA diet, $\mathrm{n}=6$ ). Ingredients, chemical composition and FA profile of the experimental diets have been reported previously (Bichi et al., 2013). Fresh diets were offered daily ad libitum at 0900 and $1900 \mathrm{~h}$ and clean water was always available. Ewes were milked twice daily at 
approximately 0830 and $1830 \mathrm{~h}$ in a $1 \times 10$ stall milking parlor (DeLaval, Madrid, Spain) throughout the $54 \mathrm{~d}$ experiment.

\subsection{Measurements, Sampling Procedures and Chemical Analysis}

Blood samples from the jugular vein were individually collected in 10-mL Vacutainer tubes (BD Vacutainer, Plymouth, UK) containing lithium heparin, before the morning milking on d 54. Plasma obtained after centrifugation $\left(3,000 \mathrm{rpm}, 10 \mathrm{~min}, 4^{\circ} \mathrm{C}\right)$ was stored at $-30^{\circ} \mathrm{C}$. Concentrations of glucose, triacylglycerol (TAG), BHBA, and NEFA were analyzed at the Veterinary Diagnostics Laboratory, College of Veterinary Medicine, University of Illinois. Concentration of insulin was analyzed using a commercial kit from Mercodia (Cat\#10-1201-01). Leptin, growth hormone (GH), and IGF-1 were measured via Radioimmunoassay (RIA).

At the end of the experiment, the ewes were slaughtered humanely via intravenous injection of an euthanasia solution (T-61, Intervet, Salamanca, Spain). Then, mammary, subcutaneous adipose from the tail-head region, and liver tissue samples were collected from each animal under sterile conditions. Tissue samples were immediately frozen in liquid nitrogen and stored at $-80^{\circ} \mathrm{C}$ until RNA extraction.

\subsection{RNA Extraction, Quantitative Reverse Transcription-PCR, Normalization, and Percentage}

\section{Relative mRNA abundance}

Complete details of these procedures can be found in the Supplemental material. Briefly, the total RNA of mammary, adipose and liver tissue was extracted using ice-cold Trizol (Invitrogen Corp., Carlsbad, CA) as described by Loor et al. (2005). Genomic DNA was removed using RNeasy Mini Kit columns (Qiagen, Hilden, Germany). The purity and concentration of the RNA 
from each sample were measured using a Nanodrop ND-1000 spectrophotometer (NanoDrop Technologies, Wilmington, DE). Quantitative reverse transcription-PCR was carried out as described by Graugnard et al. (2010). The final data were normalized using the geometric mean of 4 internal control genes (UXT, EIF3K, TUBB, and YWHAZ). The relative \% mRNA abundance for each gene was calculated using the median $\Delta \mathrm{Ct}$ values, corrected for the efficiency of PCR amplification (Bionaz and Loor, 2008).

\subsection{Statistical Analysis}

Data were analyzed using the MIXED procedure of SAS (Version 9.2; SAS Institute Inc., Cary, NC). The statistical model included the fixed effect of experimental treatment and the random effect of animal, nested within the diet to contrast the effect of the algae supplementation. Before statistical analysis, data of gene expression were log-transformed $\left(\log _{2}\right.$

scale). The UNIVARIATE procedure of SAS was used to identified and remove outliers from the data set. Significant differences were declared at $P<0.05$ and tendencies at $P<0.10$.

\section{RESULTS}

\subsection{Plasma Metabolite Concentrations}

No differences between diets were observed for the plasma concentration of glucose, BHBA, NEFA, TAG, GH, IGF-1, insulin, and leptin concentration $(P>0.05$; Table 1). 


\section{2. mRNA Expression in Mammary, Adipose and Liver Tissue}

In mammary and adipose tissue, feeding MA had no effect $(P>0.05$; Table 2$)$ on the expression of mRNA encoding for genes associated with LCFA uptake $(L P L)$, intracellular acetate activation (ACSS2), intracellular LCFA transport (FABP3), desaturation (SCD), elongation (ELOVL6), esterification (DGAT1, DGAT2, LPIN), and de novo FA synthesis (ACACA, FASN). Furthermore, MA did not affect $(P>0.05)$ the expression of transcription regulators (INSIG1, MED1, PPARG, RXRA, SCAP, SREBF1, THRSP). Expression of milk fat globule membrane proteins (BTN1A1, XDH) in mammary tissue did not differ $(P>0.05)$ due to MA.

In the liver, there were no differences $(P>0.05)$ between treatments in mRNA encoding genes associated with lipoprotein metabolism (APOB), LCFA oxidation (ACOX1, CPT1A) and regulation of transcription (PPARA, RXRA); whereas mRNA expression of HMGCS2, a gene associated with ketogenesis, was greater $(P<0.05)$ in response to SOMA (Table 2).

\subsection{Percentage Relative mRNA Abundance Among Measured Genes}

Analysis of percentage relative mRNA is presented in Figure 1. Results revealed that in mammary gland tissue the most-abundant genes, accounting for $>20 \%$ of total measured mRNAs, were BTN1A1 (27\%), SCD (24\%), LPL (24\%), and XDH (21\%). The abundance of PPARG and INSIG1 was $0.04 \%$ and $2.2 \%$ compared with SREBF1 and THRSP which averaged $0.002 \%$ and $0.001 \%$. All other genes had relative abundance $<1.0 \%$.

In the adipose tissue the highest relative $\%$ mRNA abundance was observed for FABP4 (47\%) followed by SCD (31\%) and LPL (13\%). The abundance of PPARG was $\sim 1 \%$ and that of THRSP and SREBF1 (the least-abundant gene) $1.4 \%$ and $0.003 \%$. Expression of INSIG1 averaged $0.45 \%$ 
and, except for ACACA (1.8\%) and ELOVL6 (2.5\%), most other lipogenic and esterification enzymes had relative abundance $<1.0 \%$.

In the liver the highest relative $\%$ mRNA abundance was observed for APOB $(85 \%)$. The abundance of PPARA was markedly lower (0.25\%) compared with RXRA (6.3\%) and the ketogenic enzyme HMGCS2 (7.3\%). The lowest abundance was observed for CPT1A1 (0.13\%).

\section{DISCUSSION}

As pointed out in the companion study (Bichi et al., 2013), it was evident that the addition of MA to a linoleic acid-rich diet in dairy sheep not only led to a lower milk fat yield and content, but also to an important change in milk FA profile, with a strong decrease in the concentration of 18:0 and cis-9 18:1 and an increase in trans-10 18:1, as well as cis-9, trans-11 18:2 and n-3 PUFA (Table 1). Therefore, the objective of the present study was to investigate if the MFD induced by MA and the related changes in milk FA profile are associated with a coordinated down-regulation in mRNA expression of genes with key functions in the overall process of milk fat synthesis as recently observed in CLA-induced MFD (Hussein et al., 2013).

\subsection{Mammary Lipid Metabolism}

The changes in milk FA profile and the MFD due to SOMA were not associated with statistical differences in mRNA expression of mammary genes at the end of the $54 \mathrm{~d}$ feeding period. This contrasts recent findings by Hussein et al. (2013) during CLA-induced MFD in ewes where the remarkable increase in milk trans-10, cis-12 18:2 concentration was correlated with the coordinated downregulation in transcript abundance of lipogenic enzymes involved in mammary lipid synthesis. Even though a slight but significant increase of trans-10, cis-12 18:2 
concentration also was evident in the present study (Table 1), our previous study partly ruled out an involvement of this CLA in causing and maintaining MFD due to feeding SOMA because of its low content and the lack of correlation with milk fat content (Bichi et al., 2013). The lack of difference in mRNA expression of mammary genes in our study is consistent with data from cows fed fish oil and experiencing MFD demonstrated that changes in the mammary transcriptome, as well as in milk FA profile, occur relatively quickly after initiation of treatments (Invernizzi et al., 2010) such that once milk fat concentration was set and remained nearly unchanged, there were no differences in gene expression despite marked MFD.

The absence of differences in mammary mRNA expression of genes involved in the de novo synthesis $(A C A C A, F A S N)$, as well as uptake, transport and trafficking of FA in the cells (LPL, $F A B P 3)$ or coding for the major proteins of the milk fat globule membrane (BTN1A1, XDH), was similar to previous observations in goats fed plant oils (Ollier et al., 2009; Bernard et al., 2012). In relative terms our data revealed that sheep mammary tissue expresses similar amounts of BTN1A1 and $X D H$, while in cows $X D H$ is more abundant (Bionaz and Loor, 2008). Conversely, marine lipid in cows has sometimes been associated with a down-regulation of mammary $L P L$ (Ahnadi et al., 2002; Harvatine and Bauman, 2006). The marked abundance of LPL relative to both ACACA and FASN in our study contrasts with data from cows in which both LPL and FASN were among the most-abundant genes during lactation (Bionaz and Loor, 2008). Such differences, however, might be attributable to the fact that we supplemented oil and therefore more $L P L$ was probably necessary to handle an increase in circulating chylomicrons and very low density lipoproteins (Thering et al., 2009).

In accordance with the present study, Bernard et al. (2010) reported no changes in SCD expression in goats despite a putative decreased supply of 18:0 from the rumen. Desaturation of 
18:0 in cis-9 $18: 1$ by mammary $\Delta 9$-desaturase is considered the predominant mechanism that maintains and regulates milk fluidity (Shingfield et al., 2010). The response of SCD in cows fed a blend of soybean and fish oil for 4-d was non-significant in the study of Harvatine and Bauman (2006); whereas, Invernizzi et al. (2010) reported a gradual up-regulation of SCD over time as a consequence of the reduction in 18:0 supply from the rumen induced by dietary fish oil feeding for $3 \mathrm{wk}$. The analysis of percentage relative mRNA abundance among the genes measured in the present study revealed that, despite the lack of difference in expression between treatments, SCD was one of the most abundant genes involved in mammary lipid metabolism (Fig. 1). Its relative abundance was similar to that observed in bovine mammary tissue during lactation (Bionaz and Loor, 2008). Thus, just as in cows fed fish oil (Invernizzi et al., 2011), it appears that when the diet is supplemented with marine lipids, milk fat synthesis in sheep also is dependent on other factors such as endogenous synthesis of oleic acid from rumen-derived 18:0.

A recent in vitro study with bovine kidney cells demonstrated that dietary 16:0, 20:5 and 22:6 n-3 LCFA, whose content was significantly greater in SOMA than SO (Bichi et al., 2013), are able to modulate lipid metabolism by increasing the expression of some key transcription factors or their co-activators (Bionaz et al., 2012). The fact that MA did not affect transcription regulators of milk fat synthesis in the present study partly differs from data in the bovine during MFD (Invernizzi et al., 2010; Harvatine and Bauman, 2006; Bauman et al., 2011). Speciesspecific differences among ruminants in the response of milk fat secretion and composition cannot be discarded to explain these results. This point is particularly relevant because our analyses revealed that expression of PPARG and INSIG1 is markedly greater relative to SREBF1, which is opposite to cows (Bionaz and Loor, 2008). This suggests a different adaptive response to the reduction in milk fat synthesis between lactating dairy cows and ewes. Even though the 
present study analyzed only one time point, our results underscore the importance of PPARG in the control of milk fat synthesis in sheep.

To further clarify mechanisms, an investigation of the temporal adaptation of the transcriptome in sheep mammary tissue is needed. Particularly to better understand the role of molecular mechanisms in this species as it relates to the supply of dietary and/or ruminallyderived long-chain FA.

\subsection{Adaptations of Peripheral Tissues to Changes in Milk FA Secretion}

Despite the high percentage of mRNA abundance of some key lipid-related genes such as FABP4, SCD, and LPL (see Fig. 1), on d 54 there was no difference between treatments on mRNA expression of genes encoding for lipid metabolism-related networks in subcutaneous adipose and liver tissue. A similar lack of response was observed in the expression pattern of $L P L, A C A C A, F A S N$, of $S C D$ in adipose tissue of goats receiving a diet rich in n-3 PUFA (i.e., linseed oil) for $21 \mathrm{~d}$ (Bernard et al., 2009a,b). These results contrast the observed up-regulation at $21 \mathrm{~d}$ of feeding of several lipid-related genes (particularly, $L P L$ and $S C D$ ) in adipose tissue of cows with MFD in response to supplemental fish oil (Thering et al., 2009), suggesting that the energy spared from reduced milk fat synthesis might be partitioned towards non-mammary tissues, specifically adipose (Harvatine et al., 2009). However, based on mammary and adipose data from studies evaluating long-term nutritional regulation of milk fat synthesis during MFD (Thering et al., 2009; Invernizzi et al., 2010) it is not possible to conclude that in the ovine MA did not affect the lipogenic network in subcutaneous adipose tissue. It is likely that control mechanisms regulating fat synthesis were established before the time of sampling in the present study. Support for this is the fact that in the parent study involving all animals (Bichi et al., 2013) 
there was a clear temporal adaptation in the profile of FA in milk, as shown previously in cows (Shingfield et al., 2006).

The relative abundance of mammary FABP3 $(0.52 \%$ of total measured genes $)$ and adipose FABP4 (47\% of total measured genes), along with low DGAT1 $(0.005 \%)$ in mammary and higher DGAT2 $(0.05 \%)$ in adipose, are suggestive of active utilization of LCFA in adipose likely for esterification into triacylglycerol (Graugnard et al., 2009). However, this hypothesis is contrasted by the absence of differences in concentrations of NEFA, insulin and glucose, which are known to be involved in the regulation of adipose lipogenesis (Vernon et al., 1980). Similar to our study, no effect on plasma concentration of metabolites, including glucose, NEFA, BHBA, or metabolic hormones, such as leptin, insulin and IGF-1, were observed during short(Baumgard et al., 2000; 2002) and longer-term MFD (Thering et al., 2009; Oliveira et al., 2012).

The lack of change in liver mRNA expression of genes encoding proteins associated with cholesterol and lipoprotein metabolism $(A P O B)$, FA oxidation $(A C O X 1, C P T 1 A)$ and with regulation of oxidation and ketogenesis (PPARA, RXRA) is in agreement with recent findings in dairy cows with MFD induced by supplemental CLA (Schlegel et al., 2012). There was evidence, indeed, that 14 wk of CLA supplementation persistently decreased the milk fat content without apparently influencing hepatic lipid metabolism and plasma concentration of TAG (Schlegel et al., 2012).

Regression analysis revealed a weak negative correlation between HMGCS2 mRNA expression and plasma BHBA $(\mathrm{r}=-0.49, P<0.01)$ or NEFA $(\mathrm{r}=-0.50, P<0.01)$ concentrations. The lack of a strict interdependence between HMGCS2, a key enzyme controlling hepatic ketogenesis, and BHBA agrees with the study of van Dorland et al. (2009), in which the increase in BHBA in cows after parturition was not associated with any increase in HMGCS2 expression. 
However, the up-regulation of this gene was in line with the numerically, albeit not statistically significant, greater PPARA and RXRA suggesting a mechanistic response in liver to handle greater flux of LCFA as a result of MFD. Recently, an in vitro study provided support for several of the major LCFA found in SOMA as being PPARA agonists (Bionaz et al., 2012) and the present results seem to corroborate the suggestion that, once activated, PPARA is able to upregulate target genes associated with ketogenesis (Loor et al., 2005). Consistent also with previous researches in dairy goats (Bernard et al., 2009a,b), the present results would indicate that hepatic lipid metabolism had a low relevance in nutritional mechanisms altering milk FA composition.

\section{CONCLUSIONS}

Altogether the present results highlight several differences among ruminant species in the mechanisms regulating the response to an MFD diet not only at the mammary level but also in adipose depots and liver. Transcriptional control mechanisms regulating mammary fat synthesis during long-term MA-induced MFD in sheep likely were established during earlier stages of the feeding period. Further studies are necessary to clarify the role of the transcriptome on the regulation of the onset of MFD in dairy ewes.

\section{ACKNOWLEDGMENTS}

This work was supported in part by the Spanish Ministry of Economy and Competitiveness (MINECO; AGL2011-23700) and by the 2011 International Seed Grants Program College of Agricultural, Consumer and Environmental Sciences, University of Illinois

(Urbana). E. Bichi gratefully acknowledges receipt of a predoctoral grant from the Spanish 
National Research Council (CSIC; JAE Programme) supported by European Social Fund. The authors thank the staff from the Instituto de Ganadería de Montaña (León, Spain) for their help in the field work and laboratory analysis. Special gratitude is extended to M. J. Khan, S. J. Moisá, J. S. Osorio, and Dr. A. Naeem and D. E. Graugnard (University of Illinois, Urbana) for the help during gene expression analysis.

\section{REFERENCES}

Agazzi, A., Invernizzi G., Campagnoli A., Ferroni M., Fanelli A., Cattaneo D., Galmozzi A., Crestani M., Dell'Orto V., Savoini G., 2010. Effect of different dietary fats on hepatic gene expression in transition dairy goats. Small Rumin. Res. 93, 31-40.

Ahnadi, C., Beswick, N., Delbecchi, L., Kennelly J., Lacasse P., 2002. Addition of fish oil to diets for dairy cows. II. Effects on milk fat and gene expression of mammary lipogenic enzymes. J. Dairy Res. 69, 521-531.

Bauman, D. E., Harvatine K. J., Lock, A. L., 2011. Nutrigenomics, rumen-derived bioactive fatty acids, and the regulation of milk fat synthesis. Annu. Rev. Nutr. 31, 299-319.

Baumgard, L. H., Corl, B. A., Dwyer, D. A., Saebø A., Bauman, D. E., 2000. Identification of the conjugated linoleic acid isomer that inhibits milk fat synthesis. Am. J. Physiol. Regulatory Integrative Comp. Physiol. 278, R179-R184.

Baumgard, L. H., Corl, B. A., Dwyer D. A., Bauman, D. E., 2002. Effects of conjugated linoleic acids (CLA) on tissue response to homeostatic signals and plasma variables associated with lipid metabolism in lactating dairy cows. J. Anim. Sci. 80, 1285-1293. 
Bernard, L., Bonnet, M., Leroux, C., Shingfield, K. J., Chilliard, Y., 2009a. Effect of sunflowerseed oil and linseed oil on tissue lipid metabolism, gene expression, and milk fatty acid secretion in alpine goats fed maize silage-based diets. J. Dairy Sci. 92, 6083-6094.

Bernard, L., Leroux, C., Faulconnier, Y., Durand, D., Shingfield, K. J., Chilliard, Y., $2009 \mathrm{~b}$. Effect of sunflower-seed oil or linseed oil on milk fatty acid secretion and lipogenic gene expression in goats fed hay-based diets. J. Dairy Res. 76, 241-248.

Bernard, L., Mouriot, J., Rouel, J., Glasser, F., Capitan, P., Pujos-Guillot, E., Chardigny J. M., Chilliard, Y., 2010. Effects of fish oil and starch added to a diet containing sunflower-seed oil on dairy goat performance, milk fatty acid composition and in vivo $\Delta 9$-desaturation of $\left[{ }^{13} \mathrm{C}\right]$ vaccenic acid. Br. J. Nutr. 104, 346-354.

Bernard, L., Leroux, C., Rouel, J., Bonnet, M., Chilliard, Y., 2012. Effect of level and type of starchy concentrate on tissue lipid metabolism, gene expression and milk fatty acid secretion in alpine goats receiving a diet rich in sunflower-seed oil. Br. J. Nutr. 107, 1147-1159.

Bichi, E., Hervás, G., Toral, P. G., Loor, J. J., Frutos, P., 2013. Milk fat depression induced by dietary marine algae in dairy ewes: Persistency of milk fatty acid composition and animal performance responses. J. Dairy Sci. 96, 524-532.

Bionaz, M., Loor, J. J., 2008. Gene networks driving bovine milk fat synthesis during the lactation cycle. BMC Genomics 9, 366.

Bionaz, M., Thering, B. J., Loor, J. J., 2012. Fine metabolic regulation in ruminants via nutrientgene interactions: Saturated long-chain fatty acids increase expression of genes involved in lipid metabolism and immune response partly through PPAR-alpha activation. Br. J. Nutr. $107,179-191$. 
Capper, J. L., Wilkinson, R. G., Mackenzie, A. M., Sinclair, L. A., 2007. The effect of fish oil supplementation of pregnant and lactating ewes on milk production and lamb performance. Animal 1, 889-898.

Graugnard, D. E., Piantoni, P., Bionaz, M., Berger, L. L., Faulkner D. B., Loor, J. J. 2009. Adipogenic and energy metabolism gene networks in longissimus lumborum during rapid post-weaning growth in Angus and Angus x Simmental cattle fed high-starch or low-starch diets. BMC Genomics 10,142.

Graugnard, D. E., Berger, L. L., Faulkner, D. B., Loor, J. J., 2010. High-starch diets induce precocious adipogenic gene network up-regulation in longissimus lumborum of early-weaned angus cattle. Br. J. Nutr. 103, 953-963.

Harvatine, K. J., Bauman, D. E., 2006. SREBP1 and thyroid hormone responsive spot 14 (S14) are involved in the regulation of bovine mammary lipid synthesis during diet-induced milk fat depression and treatment with CLA. J. Nutr. 136, 2468-2474.

Harvatine, K. J., Perfield II, J. W., Bauman, D. E. 2009. Expression of enzymes and key regulators of lipid synthesis is upregulated in adipose tissue during CLA-induced milk fat depression in dairy cows. J. Nutr. 139, 849-854.

Hussein, M., Harvatine, K. J., Weerasinghe, W. M. P. B., Sinclair, L. A., Bauman, D. E., 2013. Conjugated linoleic acid-induced milk fat depression in lactating ewes is accompanied by reduced expression of mammary genes involved in lipid synthesis. J. Dairy Sci. 96, 38253834.

Invernizzi, G., Thering, B. J., McGuire, M. A., Savoini, G., Loor, J. J., 2010. Sustained upregulation of stearoyl-CoA desaturase in bovine mammary tissue with contrasting changes 
in milk fat synthesis and lipogenic gene networks caused by lipid supplements. Funct. Integr. Genomics 10, 561-575.

Kadegowda, A. K. G., Bionaz, M., Piperova, L. S., Erdman, R. A., Loor, J. J., 2009. Peroxisome proliferator-activated receptor-gamma activation and long-chain fatty acids alter lipogenic gene networks in bovine mammary epithelial cells to various extents. J. Dairy Sci. 92, 42764289.

Li, X. Z., Yan, C. G., Lee, H. G., Choi, C. W., Song, M. K., 2012. Influence of dietary plant oils on mammary lipogenic enzymes and the conjugated linoleic acid content of plasma and milk fat of lactating goats. Anim. Feed Sci. Technol. 174, 26-35.

Lock, A. L., Teles, B. M., Perfield II, J. W., Bauman, D. E., Sinclair, L. A., 2006. A conjugated linoleic acid supplement containing trans-10, cis-12 reduces milk fat synthesis in lactating sheep. J. Dairy Sci. 89, 1525-1532.

Loor, J. J., Dann, H. M., Everts, R. E., Oliveira, R., Green, C. A., Janovick Guretzky, N. A., Rodriguez-Zas, S. L., Lewin, H. A., Drackley, J. K., 2005. Temporal gene expression profiling of liver from periparturient dairy cows reveals complex adaptive mechanisms in hepatic function. Physiol. Genomics 23, 217-226.

Oliveira, D. E., Gama, M. A. S., Fernandes, D., Tedeschi, L. O., Bauman, D. E., 2012. An unprotected conjugated linoleic acid supplement decreases milk production and secretion of milk components in grazing dairy ewes. J. Dairy Sci. 95, 1437-1446.

Ollier, S., Leroux, C., de la Foye, A., Bernard, L., Rouel, J., Chilliard, Y., 2009. Whole intact rapeseeds or sunflower oil in high-forage or high-concentrate diets affects milk yield, milk composition, and mammary gene expression profile in goats. J. Dairy Sci. 92, 5544-5560. 
Papadopoulos, G., Goulas, C., Apostolaki, E., Abril, R., 2002. Effects of dietary supplements of algae, containing polyunsaturated fatty acids, on milk yield and the composition of milk products in dairy ewes. J. Dairy Res. 69, 357-365.

Piperova, L., Teter, B., Bruckental, I., Sampugna, J., Mills, S., Yurawecz, M., Fritsche, J., Ku, K., Erdman, R., 2000. Mammary lipogenic enzyme activity, trans fatty acids and conjugated linoleic acids are altered in lactating dairy cows fed a milk fat-depressing diet. J. Nutr. 130, $2568-2574$.

Reynolds, C. K., Cannon, V. L., Loerch, S. C., 2006. Effects of forage source and supplementation with soybean and marine algal oil on milk fatty acid composition of ewes. Anim. Feed Sci. Technol. 131, 333-357.

Schlegel, G., Ringseis, R., Windisch, W., Schwarz, F. J., Eder, K., 2012. Effects of rumenprotected mixture of conjugated linoleic acids on hepatic expression of genes involved in lipid metabolism in dairy cows. J. Dairy Sci. 95, 3905-3918.

Shingfield, K. J., Reynolds, C. K., Hervás, G., Griinari, J. M., Grandison, A. S., Beever, D. E., 2006. Examination of the persistency of milk fatty acid composition responses to fish oil and sunflower oil in the diet of dairy cows. J. Dairy Sci. 89, 714-732.

Shingfield, K. J., Bernard L., Leroux C., Chilliard, Y. 2010. Role of trans fatty acids in the nutritional regulation of mammary lipogenesis in ruminants. Animal 4:1140-1166.

Shingfield, K. J., Bonnet, M., Scollan, N. D., 2013. Recent developments in altering the fatty acid composition of ruminant-derived foods. Animal 7 S1, 132-162.

Sinclair, L. A., Weerasinghe, W. M. P. B., Wilkinson, R. C., de Veth, M. J., Bauman, D. E., 2010. A supplement containing trans-10, cis-12 conjugated linoleic acid reduces milk fat 
yield but does not alter organ weight or body fat deposition in lactating ewes. J. Nutr. 140, 1949-1955.

Thering, B. J., Graugnard, D. E., Piantoni, P., Loor, J. J., 2009. Adipose tissue lipogenic gene networks due to lipid feeding and milk fat depression in lactating cows. J. Dairy Sci. 92, 4290-4300.

Toral, P. G., Frutos, P., Hervás, G., Gómez-Cortés, P., Juárez, M., de la Fuente, M. A. 2010 b. Changes in milk fatty acid profile and animal performance in response to fish oil supplementation, alone or in combination with sunflower oil, in dairy ewes. J. Dairy Sci. 93, $1604-1615$.

Toral, P. G., Hervás, G., Gómez-Cortés, P., Frutos, P., Juárez, M., de la Fuente, M. A. 2010a. Milk fatty acid profile and dairy sheep performance in response to diet supplementation with sunflower oil plus incremental levels of marine algae. J. Dairy Sci. 93, 1655-1667.

Toral, P.G., Bernard, L., Delavaud, C., Gruffaut, D., Leroux, C., Chilliard, Y., 2013. Effects of fish oil and additional starch on tissue fatty acid profile and lipogenic gene mRNA abundance in lactating goats fed a diet containing sunflower-seed oil. Animal 7, 948-956.

Tsiplakou, E., Flemetakis, E., Kalloniati, C., Papadomichelakis, G., Katinakis, P., Zervas, G., 2009. Sheep and goats differences in CLA and fatty acids milk fat content in relation with mRNA stearoyl-CoA desaturase and lipogenic genes expression in their mammary gland. J. Dairy Res. 76, 392-401.

van Dorland, H. A., Richter, S., Morel, I., Doherr, M. G., Castro, N., Bruckmaier, R. M., 2009. Variation in hepatic regulation of metabolism during the dry period and in early lactation in dairy cows. J. Dairy Sci. 92, 1924-1940. 
Vernon, R. G., 1980. Lipid metabolism in the adipose tissue of ruminant animals. Prog. Lipid Res. 19, 23-106. 
Table 1. Milk and fat yield, fat content, and fatty acid (FA) profile in dairy ewes after 54 days on the experimental diets ${ }^{1}$

\begin{tabular}{|c|c|c|c|c|}
\hline \multirow[b]{2}{*}{ Item } & \multicolumn{2}{|c|}{ Treatment } & \multirow[b]{2}{*}{ SEM } & \multirow[b]{2}{*}{$P$-value ${ }^{2}$} \\
\hline & SO & SOMA & & \\
\hline Milk yield, $\mathrm{g} / \mathrm{d}$ & 1,274 & 1,608 & 204.6 & 0.26 \\
\hline Fat yield, $\mathrm{g} / \mathrm{d}$ & 80.9 & 75.1 & 13.19 & 0.75 \\
\hline Fat content, $\mathrm{g} / 100 \mathrm{~g}$ of raw milk & 6.57 & 4.80 & 0.323 & 0.003 \\
\hline \multicolumn{5}{|l|}{$\mathrm{FA}, \mathrm{g} / 100 \mathrm{~g}$ of total FA } \\
\hline 4:0 & 3.60 & 3.50 & 0.146 & 0.65 \\
\hline 6:0 & 2.65 & 2.15 & 0.240 & 0.16 \\
\hline 8:0 & 2.46 & 1.85 & 0.278 & 0.14 \\
\hline 10:0 & 7.01 & 5.44 & 0.837 & 0.20 \\
\hline 12:0 & 3.83 & 3.48 & 0.342 & 0.46 \\
\hline 14:0 & 9.89 & 11.16 & 0.490 & 0.07 \\
\hline cis-9 14:1 & 0.25 & 0.28 & 0.042 & 0.55 \\
\hline 15:0 & 0.72 & 0.73 & 0.026 & 0.72 \\
\hline 16:0 & 20.88 & 23.36 & 0.860 & 0.06 \\
\hline cis-9 16:1 & 0.76 & 0.87 & 0.093 & 0.41 \\
\hline 17:0 & 0.44 & 0.42 & 0.028 & 0.64 \\
\hline 18:0 & 8.26 & 2.04 & 0.553 & $<0.001$ \\
\hline $\operatorname{cis}-918: 1^{3}$ & 16.80 & 10.33 & 1.115 & 0.002 \\
\hline Other cis-18:1 & 1.27 & 1.21 & 0.120 & 0.70 \\
\hline trans-10 18:1 & 0.77 & 6.91 & 1.465 & 0.01 \\
\hline trans-11 18:1 & 5.89 & 8.85 & 1.182 & 0.10 \\
\hline Other trans-18:1 & 2.49 & 3.04 & 0.200 & 0.07 \\
\hline cis- 9, cis-12 $18: 2^{4}$ & 2.57 & 2.01 & 0.213 & 0.08 \\
\hline cis-9, trans-11 $18: 2^{5}$ & 2.93 & 3.52 & 0.670 & 0.53 \\
\hline trans-9, cis-11 18:2 & 0.14 & 0.26 & 0.038 & 0.04 \\
\hline trans-10, cis-12 18:2 & 0.04 & 0.07 & 0.006 & 0.01 \\
\hline cis- 9, cis- 12, cis-15 18:3 & 0.41 & 0.31 & 0.041 & 0.10 \\
\hline cis-5, cis- 8, cis- 11, cis- 14, cis- 17 20:5 & 0.03 & 0.06 & 0.006 & $<0.001$ \\
\hline cis-4, cis-7, cis-10, cis-13, cis-16, cis-19 22:6 & 0.06 & 0.49 & 0.033 & $<0.001$ \\
\hline Other FA & 5.85 & 7.64 & 0.231 & $<0.001$ \\
\hline
\end{tabular}

\footnotetext{
${ }^{1}$ Refers to TMR containing $25 \mathrm{~g}$ of sunflower oil/kg of DM and supplemented with 0 (SO; control diet) or $8 \mathrm{~g}$ of marine algae (SOMA diet) $/ \mathrm{kg}$ of DM.

${ }^{2}$ Probability of significant differences between diets.

${ }^{3}$ Coelutes with trans-13+14 18:1.

${ }^{4}$ Coelutes with 9,15 18:2.

${ }^{5}$ Coelutes with trans-7 cis-9 18:2 + cis-14 20:1.
} 
Table 2. Concentration of plasma metabolites in dairy ewes after 54 days on the experimental $\operatorname{diets}^{\mathrm{a}}$

\begin{tabular}{|c|c|c|c|c|}
\hline \multirow[b]{2}{*}{ Item } & \multicolumn{2}{|c|}{ Treatment } & \multirow[b]{2}{*}{ SEM } & \multirow[b]{2}{*}{$P$-value ${ }^{\mathrm{b}}$} \\
\hline & SO & SOMA & & \\
\hline BHBA, mmol/L & 0.59 & 0.49 & 0.061 & 0.23 \\
\hline Glucose, $\mathrm{mg} / \mathrm{dL}$ & 49.7 & 58.8 & 4.07 & 0.13 \\
\hline $\mathrm{NEFA}, \mathrm{mmol} / \mathrm{L}$ & 0.16 & 0.12 & 0.018 & 0.19 \\
\hline Triacylglycerol, mg/dL & 34.5 & 29.4 & 4.15 & 0.38 \\
\hline Growth hormone, $\mathrm{ng} / \mathrm{mL}$ & 1.20 & 0.87 & 0.305 & 0.43 \\
\hline IGF-1, ng/mL & 219.7 & 195.9 & 14.62 & 0.26 \\
\hline Insulin, $\mu \mathrm{g} / \mathrm{L}$ & 0.59 & 0.76 & 0.172 & 0.49 \\
\hline Leptin, ng/mL & 17.9 & 16.6 & 2.062 & 0.66 \\
\hline NEFA:Insulin & 0.32 & 0.21 & 0.067 & 0.24 \\
\hline Glucose:Insulin & 113.2 & 82.6 & 16.49 & 0.20 \\
\hline IGF-1:GH & 242.9 & 260.1 & 89.72 & 0.89 \\
\hline
\end{tabular}


Table 3. Gene expression ( $\log _{2}$-transformed) in mammary, adipose and liver tissue in dairy ewes after 54 days on the experimental diets ${ }^{\mathrm{a}}$

\begin{tabular}{|c|c|c|c|c|}
\hline & \multicolumn{2}{|c|}{ Treatment } & \multirow[b]{2}{*}{ SEM } & \multirow[b]{2}{*}{$P$-value ${ }^{b}$} \\
\hline & $\mathrm{SO}$ & SOMA & & \\
\hline \multicolumn{5}{|l|}{ Mammary } \\
\hline$A C A C A$ & -1.03 & -1.26 & 0.210 & 0.43 \\
\hline ACSS2 & 1.75 & 1.36 & 0.325 & 0.38 \\
\hline BTN1A1 & 1.51 & 1.20 & 0.342 & 0.49 \\
\hline DGAT1 & 0.27 & 0.11 & 0.317 & 0.71 \\
\hline ELOVL6 & -5.13 & -5.20 & 0.389 & 0.89 \\
\hline FABP3 & 1.40 & 1.05 & 0.620 & 0.67 \\
\hline FASN & -1.28 & -1.66 & 0.470 & 0.54 \\
\hline INSIG1 & 0.77 & 0.28 & 0.325 & 0.27 \\
\hline LPIN1 & 0.77 & 0.59 & 0.464 & 0.78 \\
\hline$L P L$ & 1.08 & 1.06 & 0.237 & 0.96 \\
\hline MED1 & 0.03 & -0.06 & 0.077 & 0.39 \\
\hline PPARG & -1.34 & -1.79 & 0.350 & 0.35 \\
\hline$R X R A$ & -0.24 & -0.31 & 0.052 & 0.35 \\
\hline SCAP & 0.55 & 0.50 & 0.102 & 0.72 \\
\hline$S C D$ & 0.82 & 0.54 & 0.241 & 0.41 \\
\hline SREBF1 & -0.03 & -0.33 & 0.323 & 0.50 \\
\hline THRSP & -10.59 & -10.50 & 0.693 & 0.93 \\
\hline$X D H$ & 1.41 & 0.97 & 0.245 & 0.21 \\
\hline \multicolumn{5}{|l|}{ Adipose } \\
\hline$A C A C A$ & 0.61 & 1.13 & 0.411 & 0.37 \\
\hline ACSS2 & -0.35 & -0.48 & 0.229 & 0.69 \\
\hline$A D F P$ & -4.26 & -4.05 & 0.307 & 0.63 \\
\hline DGAT2 & -0.72 & -0.19 & 0.675 & 0.58 \\
\hline ELOVL6 & 0.44 & 1.16 & 0.525 & 0.33 \\
\hline FABP4 & 0.93 & 0.98 & 0.194 & 0.86 \\
\hline FASN & -2.79 & -2.88 & 0.717 & 0.93 \\
\hline INSIG1 & -1.89 & -1.88 & 0.419 & 0.99 \\
\hline LPIN1 & 0.12 & 0.19 & 0.240 & 0.83 \\
\hline$L P L$ & -0.26 & -0.02 & 0.302 & 0.56 \\
\hline MED1 & -0.18 & -0.34 & 0.112 & 0.31 \\
\hline PPARG & 2.48 & 2.90 & 0.232 & 0.22 \\
\hline$R X R A$ & 0.96 & 0.58 & 0.165 & 0.12 \\
\hline SCAP & 0.55 & 0.64 & 0.235 & 0.80 \\
\hline$S C D$ & -0.00 & 0.81 & 0.570 & 0.32 \\
\hline SREBF1 & 0.71 & 0.63 & 0.373 & 0.87 \\
\hline THRSP & 0.30 & 0.66 & 0.976 & 0.79 \\
\hline
\end{tabular}

Liver 


\begin{tabular}{lcccc} 
ACOX1 & -1.37 & -1.12 & 0.207 & 0.40 \\
APOB & -0.58 & -0.36 & 0.195 & 0.42 \\
CPT1A & -0.83 & -0.75 & 0.110 & 0.58 \\
HMGCS2 & -0.96 & -0.26 & 0.204 & 0.03 \\
PPARA & -0.60 & -0.36 & 0.118 & 0.17 \\
RXRA & 0.03 & 0.17 & 0.148 & 0.51 \\
\hline${ }^{\mathrm{a}}$ Refers to TMR containing $25 \mathrm{~g}$ of sunflower oil/kg of DM and supplemented with 0 (SO; \\
control diet) or 8 g of marine algae (SOMA diet)/kg of DM. \\
brobability of significant differences between diets.
\end{tabular}




\section{SUPPLEMENTAL MATERIAL}

\section{RNA extraction}

RNA samples were extracted using established protocols (Loor et al., 2005). Briefly, tissue was weighed ( $\sim 0.3 \mathrm{~g}$ for mammary gland, $\sim 1 \mathrm{~g}$ for adipose tissue, $\sim 0.1 \mathrm{~g}$ for liver) and placed straightway inside a $15 \mathrm{~mL}$ centrifuge tube (Cat. No. 430052, Corning Inc. ${ }^{\circledR}$ ) with $1 \mu 1$ of Linear Acrylamide (Ambion ${ }^{\circledR}$ Cat. No. 9520, Austin, TX) as a co-precipitant, and $5 \mathrm{~mL}$ ice-cold Trizol reagent (Invitrogen Corp., Carlsbad, CA). Tissue was then homogenized. Genomic DNA was removed from RNA with DNase using RNeasy Mini Kit columns (Qiagen, Hilden, Germany). RNA concentration was measured using a Nano-Drop ND-1000 spectrophotometer (Nano-Drop Technologies,). The purity of RNA $\left(\mathrm{A}_{260} / \mathrm{A}_{280}\right)$ for all samples was above 1.81 . Also, RNA quality was evaluated using the Agilent Bioanalyzer system (Agilent Technologies,). The average RIN number of the samples used was $>8.0$.

\section{qPCR Analysis}

For qPCR analysis, cDNA was synthesized using 100 ng RNA, $1 \mu \mathrm{L}$ dT18 (Operon Biotechnologies, Huntsville, AL), $1 \mu \mathrm{L} 10 \mathrm{mmol} / \mathrm{L}$ dNTP mix (Invitrogen Corp., CA), $1 \mu \mathrm{L}$ random primer $\mathrm{p}(\mathrm{dN})_{6}$ (Roche Cat. No 11034731001, Indianapolis, IN), and $7 \mu \mathrm{L}$ DNase/RNase free water. The mixture was incubated at $65^{\circ} \mathrm{C}$ for $5 \mathrm{~min}$ and kept on ice for $3 \mathrm{~min}$. A total of 9 $\mu \mathrm{L}$ of master mix composed of $4.5 \mu \mathrm{L} 5 \mathrm{X}$ First-Strand Buffer, $1 \mu \mathrm{L} 0.1 \mathrm{M}$ DTT, $0.25 \mu \mathrm{L}(50 \mathrm{U})$ of SuperScript $^{\mathrm{TM}}$ III RT (Invitrogen Corp., Carlsbad, CA), $0.25 \mu \mathrm{L}$ of RNase Inhibitor (10 U, Promega, Madison, WI) and $3 \mu \mathrm{L}$ DNase/RNase free water was added. The reaction was performed in an Eppendorf Mastercycler ${ }^{\circledR}$ Gradient (Eppendorf, Hauppauge, NY) using the following temperature program: $25^{\circ} \mathrm{C}$ for $5 \mathrm{~min}, 50{ }^{\circ} \mathrm{C}$ for $60 \mathrm{~min}$ and $70{ }^{\circ} \mathrm{C}$ for $15 \mathrm{~min}$. cDNA was then diluted 1:4 (v:v) with DNase/RNase free water. 
Quantitative PCR (qPCR) was performed using $4 \mu \mathrm{L}$ diluted cDNA (dilution 1:4) combined with $6 \mu \mathrm{L}$ of a mixture composed of $5 \mu \mathrm{L}$ 1x SYBR Green master mix (Applied Biosystems, Foster City, CA), $0.4 \mu \mathrm{L}$ each of $10 \mu \mathrm{M}$ forward and reverse primers, and $0.2 \mu \mathrm{L}$ DNase/RNase free water in a MicroAmp ${ }^{\mathrm{TM}}$ Optical 384-Well Reaction Plate (Applied Biosystems, Foster City, CA). Each sample was run in triplicate and a 7 point relative standard curve plus the non-template control (NTC) were used (User Bulletin \#2, Applied Biosystems, Foster City, CA). The reactions were performed in an ABI Prism 7900 HT SDS instrument (Applied Biosystems, Foster City, CA) using the following conditions: 2 min at $50{ }^{\circ} \mathrm{C}, 10 \mathrm{~min}$ at $95^{\circ} \mathrm{C}, 40$ cycles of $15 \mathrm{~s}$ at $95^{\circ} \mathrm{C}$ (denaturation) and $1 \mathrm{~min}$ at $60^{\circ} \mathrm{C}$ (annealing + extension). The presence of a single PCR product was verified by the dissociation protocol using incremental temperatures to $95{ }^{\circ} \mathrm{C}$ for $15 \mathrm{~s}$ plus $65^{\circ} \mathrm{C}$ for $15 \mathrm{~s}$. Data were calculated with the $7900 \mathrm{HT}$ Sequence Detection Systems Software (version 2.2.1, Applied Biosystems, Foster City, CA).

\section{Selection of internal control genes}

The final data were normalized using the geometric mean of 4 selected ICG (Table S1): ubiquitously expressed transcript (UXT), eukaryotic translation initiation factor 3, subunit $\mathrm{K}$ (EIF3K), which were identified as suitable internal controls in bovine adipose and mammary tissues (Thering et al., 2009; Invernizzi et al., 2010), tyrosine 3-monooxygenase (YWHAZ), and tubulin beta, subunit $2 \mathrm{~A}$ (TUBB), which were identified as suitable internal controls in ovine tissues (Zang et al., 2011).

\section{Primer design and testing}

Primers were designed using Primer Express 3.0 with minimum amplicon size of $100 \mathrm{bp}$ and limited 3' G+C (Applied Biosystems, CA). When possible, primers were designed to fall across exon-exon junctions. Primers were aligned against publicly available databases using 
BLASTN at NCBI and UCSC's Sheep (Ovis aries) Genome Browser Gateway (Table S3). Prior to $\mathrm{qPCR}$, primers were tested in a $20 \mu \mathrm{L}$ PCR reaction using the same protocol described for qPCR except for the final dissociation protocol. For primer testing we used a pool of cDNA samples (mixture from 3 different ovine tissues) to ensure identification of desired genes. Five $\mu \mathrm{L}$ of the PCR product were run in a $2 \%$ agarose gel stained with ethidium bromide $(2 \mu \mathrm{L})$. The remaining $15 \mu \mathrm{L}$ were cleaned using QIAquick ${ }^{\circledR}$ PCR Purification Kit (QIAGEN) and sequenced at the Core DNA Sequencing Facility of the Roy J. Carver Biotechnology Center at the University of Illinois, Urbana-Champaign. Only those primers that did not present primerdimer, a single band at the expected size in the gel, and had the right amplification product (verified by sequencing) were used for qPCR. The accuracy of a primer pair also was evaluated by the presence of a unique peak during the dissociation step at the end of qPCR. Sequencing results for all genes are reported in Table S2 and in previous publication (Loor et al., 2007; Bionaz and Loor, 2008a,b; Kadegowda et al., 2009; Schmitt et al., 2011; Naeem et al., 2012; Ji et al., 2012).

Genes selected for transcript profiling in the present study were grouped as follows: FA uptake from blood, lipoprotein lipase (LPL); intracellular FA trafficking, fatty acid binding protein 3, muscle and heart (FABP3) and 4, adipocyte (FABP4); intracellular activation of VFA, acyl-CoA synthetase short-chain family member 2 (ACSS2); de novo FA synthesis, acetylcoenzyme A carboxylase $\alpha$ (ACACA), fatty acid synthase (FASN); desaturation, stearoyl-CoA desaturase $(S C D)$; triacylglycerol synthesis, diacylglycerol acyltransferase 1 and 2 (DGAT1, DGAT2), lipin 1 (LPIN1); long chain FA elongation, ELOVL family member 6 (ELOVL6); lipid droplet formation, adipose differentiation related protein (ADFP), butyrophilin, subfamily 1, member A1 (BTN1A1), xanthine dehydrogenase $(X D H)$; transcription regulation, insulin induced 
gene 1 (INSIG1), mediator of RNA polymerase II transcription subunit 1 (MED1), SREBP cleavage activating protein $(S C A P)$, sterol regulatory element-binding transcription factor 1 (SREBF1), thyroid hormone responsive SPOT14 (THRSP), peroxisome proliferator activated receptor gamma $(P P A R G)$; cholesterol transport and lipoprotein synthesis, apolipoprotein B $(A P O B)$; ketogenesis, 3-hydroxy-3-methylglutaryl-CoA synthase 12 (HMGCS2); long-chain fatty acid oxidation, acyl-CoA oxidase 1, palmitoyl (ACOX1), carnitine palmitoyl-transferase 1A $(C P T 1 A)$; transcriptional regulation of fatty acid oxidation, retinoid $\mathrm{X}$ receptor, alpha $(R X R A)$, peroxisome proliferator-activated receptor alpha (PPARA).

\section{Relative mRNA abundance among transcripts}

Efficiency of PCR amplification for each gene was calculated using the standard curve method $(\mathrm{E}=10-1 /-\log$ curve slope $)$. Relative mRNA abundance among measured genes was calculated as previously reported (Bionaz and Loor, 2007), using the inverse of PCR efficiency raised to $\Delta \mathrm{Ct}$ (gene abundance $=1 / \mathrm{E}^{\Delta \mathrm{Ct}}$, where $\Delta \mathrm{Ct}=\mathrm{Ct}$ sample - geometric mean $\mathrm{Ct}$ of 4 internal control genes). Overall mRNA abundance for each gene among all samples measured was calculated using the median $\Delta \mathrm{Ct}$. Use of this technique for estimating relative mRNA abundance among genes was necessary because relative mRNA quantification was performed using a standard curve (made from a mixture of RNA from different ovine tissues, which precluded a direct comparison among genes). Together, use of $\mathrm{Ct}$ values corrected for the efficiency of amplification plus internal control genes as baseline overcome this limitation. 
Table S1. Description of 4 internal control genes

\begin{tabular}{ll}
\hline Symbol & Entrez Gene Name \\
\hline EIF3K & Eukaryotic translation initiation factor 3, subunit K \\
TUBB & Tubulin beta, subunit 2A \\
UXT & Ubiquitously expressed transcript \\
YWHAZ & Tyrosine 3-monooxygenase \\
\hline
\end{tabular}


Table S2. Sequencing results of PCR products from primers of genes designed for this experiment. Best hits using BLASTN (http://www.ncbi.nlm.nih.gov) are shown

\begin{tabular}{|c|c|}
\hline Gene & Sequence \\
\hline ACACA & $\begin{array}{l}\text { GGGGCCCTGTCAACGGTGACGTCGGATAGCATCTCCAACTTCCTTCACTCCTTAGAGAGGGGGGGTCAAGTCCTC } \\
\text { TCTGCTCATACACTTCTAA }\end{array}$ \\
\hline ACSS2 & $\begin{array}{l}\text { CGCATCAGTCTCGGGTGCCTCACAGGGACAGACAACAAGGGTCCCACATGGGGGAATCTGGATGTTTCTCTTGAG } \\
\text { CAGGAGATGGGAC }\end{array}$ \\
\hline$A D F P$ & GCTCСTCTCTCCGTGATTGGACTGTGCCGGGAGATGGTGGCATAATGGCCAACCAGAAGATTCACGATGGCTCAA \\
\hline DGAT1 & $\begin{array}{l}\text { ACCGGTTTGTCGGATTGGGACGGCTTCCCTCCTCCCTCCCCCACTTTCATCTTAGAGACTGGCTGCATATCCGGGT } \\
\text { CAGTGTGGTTGTAA }\end{array}$ \\
\hline FABP3 & $\begin{array}{l}\text { CCCTTCCTCTCGTGAGTCCTGTGCCTAAAATAACCTTGCTCCTGAATGGACCCAAAAACCTAGAGGAATGGGAAT } \\
\text { GAGAA }\end{array}$ \\
\hline FABP4 & $\begin{array}{l}\text { AGAGACTTCACACGTGGGATGGAATCACCCCATAAAGAGAAAACTTGTTGGATGATAAGCCTGGTGCTGGAATGT } \\
\text { ACCCAGCAGCACCTTCATCTAAGGTTTAA }\end{array}$ \\
\hline$L P L$ & GACTTCGACGTCTCGTTCTCTCTTATTGACTCTCTGTTGAATGAAGAAAATCCAAGGTAAGGGCCTACCGGG \\
\hline PPARG & CAGATCTCGGGCTTGTTGACCCTTGACTGGAATGACCAAGGTAACTCTCCTAAAATACGGGCGTGCACGAGATAA \\
\hline SCD & GGGAGAAAGGCAAGGCCCAGCCTTGAGGTATGTTTGGAGAAACATCATCCTCATGGGTCTGTTACACTTGGGAA \\
\hline SREBF1 & $\begin{array}{l}\text { CACCAACGTCCGGCCCGTCAGACCCTGGTGAAGTGGCGGGGCCATCCCTGGCCACTGTGTCCACTGGTAGTGGAC } \\
\text { ACCTGTACAAGCTGCCAA }\end{array}$ \\
\hline TUBB & $\begin{array}{l}\text { CAGAGCGTCCGAACAGGACACGGCCGGCCTACCTTCGTGGGAATGGGATCCCCAACAACGTCAAGGACAGCTGG } \\
\text { TTTGGCGACATCCAA }\end{array}$ \\
\hline$X D H$ & $\begin{array}{l}\text { AGGTAGATGACTCTTCCGGGCTAGATGCCCTGCCACCCCGGAGGAAGATCCGCAATGCCTGTGTGGACAAGGTTT } \\
\text { CAAA }\end{array}$ \\
\hline YWHAZ & $\begin{array}{l}\text { GTTGTACTCTCCTTTTTGCAAGACGGAAGGGTGTCTTGAGAAAACAGCAGATGTGGCTTCGAGAATTACAGAGAG } \\
\text { AAA }\end{array}$ \\
\hline
\end{tabular}


Table S3. Sequencing results of genes using BLASTN from NCBI against nucleotide collection (nr / nt) with total score

\begin{tabular}{lll}
\hline Gene & Best hits & Score \\
\hline ACACA & $\begin{array}{l}\text { Ovis aries acetyl-CoA carboxylase alpha (ACACA), mRNA >emb|X80045.1| O. aries mRNA for } \\
\text { acetyl-CoA carboxylase }\end{array}$ & 105 \\
ACSS2 & Ovis aries acetyl-CoA synthetase 2 (ACAS2) mRNA, partial cds \\
ADFP & $\begin{array}{l}\text { Ovis aries perilipin 2 (PLIN2), mRNA >gb|EF660332.1| Ovis aries adipose differentiation-related } \\
\text { protein (ADFP) mRNA, complete cds }\end{array}$ & 53.6 \\
DGAT1 & Ovis aries diacylglycerol acyltransferase 1 (DGAT1) gene, complete cds \\
FABP3 & Ovis aries heart fatty acid binding protein (H-FABP) gene, exons 2 through 4 and partial cds \\
FABP4 & Ovis aries fatty acid binding protein 4, adipocyte (FABP4), mRNA >gb|EU301804.1| Ovis aries \\
LPL & Odipocyte fatty acid-binding protein 4 (FABP4) mRNA, complete cds & 714 \\
PPARG & Ovis aries proliferator-activated receptor gamma mRNA, partial cds & 73.4 \\
SCD & Ovis aries stearoyl-CoA desaturase (SCD) gene, complete cds \\
SREBF1 & Ovis aries sterol regulatory element-binding transcription factor 1 gene, exons 6, 7 and partial cds & 95.1 \\
TUBB & Ovis aries beta-tubulin mRNA, partial cds & 77.0 \\
XDH & Ovis aries xanthine dehydrogenase (XDH) mRNA, partial cds \\
YWHAZ & Ovis aries tyrosine 3-monooxygenase (YWHAZ) mRNA, partial cds & 84.2 \\
\hline
\end{tabular}


Table S4. Gene ID, GenBank accession number, hybridization position, sequence and amplicon size of primers for Ovis aries used to analyze gene expression by $\mathrm{qPCR}$

\begin{tabular}{|c|c|c|c|c|c|}
\hline Gene ID & Accession \# & Gene & Primers $^{1}$ & Primers (5'-3') & $\mathrm{bp}^{2}$ \\
\hline \multirow[t]{2}{*}{443186} & \multirow[t]{2}{*}{ NM_001009256.1 } & \multirow[t]{2}{*}{ ACACA } & F.2201 & ACCATGCTGGGAGTTGTCTGT & \multirow{2}{*}{118} \\
\hline & & & R.2319 & AGAAGTGTATGAGCAGAGAGGACTTG & \\
\hline \multirow[t]{2}{*}{780456} & \multirow[t]{2}{*}{ DQ272257.1 } & \multirow[t]{2}{*}{ ACSS2 } & F.197 & CGAAGCCATAAAGATCTGTCCAT & \multirow{2}{*}{106} \\
\hline & & & R.303 & ССАТСТССТGCTCAAGAGAAACA & \\
\hline \multirow{2}{*}{100125354} & \multirow[t]{2}{*}{ NM_001104932.1 } & \multirow{2}{*}{$A D F P$} & F.746 & AAGAGGCCAGGAGACCATTTC & \multirow{2}{*}{101} \\
\hline & & & R.847 & TGAGCATCGTGAATCTTCTGGTT & \\
\hline \multirow[t]{2}{*}{100126245} & \multirow[t]{2}{*}{ EU178818.1 } & \multirow[t]{2}{*}{ DGAT1 } & F.2763 & AGGGATCTGGAAAAGCTTGAATAA & \multirow[b]{2}{*}{114} \\
\hline & & & R.2877 & ACAACCACACTGACCGGATATG & \\
\hline \multirow{2}{*}{2828237} & \multirow{2}{*}{ AY157617.1 } & \multirow{2}{*}{ FABP3 } & F.1954 & AGGGCAAGAACCCCAATTAAA & \multirow{2}{*}{100} \\
\hline & & & R.2054 & СТCATTCССАТTCСТСТАGTTTTTG & \\
\hline \multirow[t]{2}{*}{100137067} & \multirow[t]{2}{*}{ NM_001114667.1 } & \multirow[t]{2}{*}{ FABP4 } & F.255 & AAACTTAGATGAAGGTGCTCTGGTACA & \multirow{2}{*}{99} \\
\hline & & & R.354 & ACATTCCAGCACCAGCTTATCA & \\
\hline \multirow[t]{2}{*}{443408} & \multirow[t]{2}{*}{ NM_001009394 } & \multirow[t]{2}{*}{$L P L$} & F.942 & TGGAGATGTGGACCAGCTAGTG & \multirow{2}{*}{9} \\
\hline & & & R.1041 & CCGGTAGGCCTTACTTGGATT & \\
\hline \multirow[t]{2}{*}{443513} & \multirow[t]{2}{*}{ FJ200441.1 } & \multirow[t]{2}{*}{$P P A R G$} & F.64 & CCGTGCAGGAGATCACAGAGT & \multirow{2}{*}{99} \\
\hline & & & R.163 & ATCTCGTGCACGCCGTATTT & \\
\hline \multirow[t]{2}{*}{443185} & FJ513370 & $S C D$ & F.1100 & GATGACATCTATGACCCAACTTACCA & 100 \\
\hline & & & R.1200 & CCCAAGTGTAACAGACCCATGA & 100 \\
\hline 100329218 & GU206528 & SREBF1 & F.152 & GGGACAAGGTTTGCTCACATG & 115 \\
\hline & & & R.267 & GGCAGCTTGTCAGTGTCCACTA & \\
\hline 100303606 & AF035420.1 & TUBB & F.181 & GAAGGAGGTAGATGAGCAGATGCT & \\
\hline & & & R.280 & GATGTCGCAAACAGCTGTCTTG & 7 \\
\hline 780499 & EF529448.1 & $X D H$ & F.631 & GCTCGAGCTCAGCACACAGA & \\
\hline & & & R.730 & TGAACTTGTCCACACAGGCATT & 9 \\
\hline 780452 & AY970970.1 & YWHAZ & F. & TGTAGGAGCCCGTAGGTCATCT & 1 \\
\hline & & & R. & TTCTCTCTGTATTCTCGAGCCATCT & 102 \\
\hline
\end{tabular}

${ }^{1}$ Primer direction ( $\mathrm{F}$ - forward; $\mathrm{R}$ - reverse) and hybridization position on the sequence.

${ }^{2}$ Amplicon size in base pair (bp). 
Table S5. Quantitative PCR performance among the genes measured in mammary,, adipose and liver tissue.

\begin{tabular}{|c|c|c|c|c|c|}
\hline Gene & Median $\mathrm{Ct}^{1}$ & Median $\Delta \mathbf{C t}^{2}$ & Slope $^{3}$ & $\left(R^{2}\right)^{4}$ & Efficiency $^{6}$ \\
\hline \multicolumn{6}{|c|}{ Mammary gland } \\
\hline$A C A C A$ & 23.77 & 0.63 & -3.16 & 0.996 & 2.07 \\
\hline ACSS2 & 23.74 & 0.60 & -2.97 & 0.990 & 2.17 \\
\hline BTN1A1 & 17.69 & -5.59 & -3.28 & 0.998 & 2.02 \\
\hline DGAT1 & 30.31 & 7.18 & -3.58 & 0.982 & 1.90 \\
\hline ELOVL6 & 27.01 & 3.73 & -3.41 & 0.988 & 1.96 \\
\hline FABP3 & 23.04 & 0.05 & -2.96 & 0.992 & 2.18 \\
\hline$F A S N$ & 23.71 & 0.52 & -2.94 & 0.979 & 2.19 \\
\hline INSIG1 & 20.70 & -2.02 & -3.29 & 0.995 & 2.01 \\
\hline LPIN1 & 24.15 & 0.88 & -3.14 & 0.990 & 2.08 \\
\hline$L P L$ & 17.27 & -4.96 & -3.01 & 0.991 & 2.15 \\
\hline MED1 & 25.03 & 3.36 & -3.59 & 0.994 & 1.90 \\
\hline$P P A R G$ & 25.64 & 3.30 & -2.96 & 0.983 & 2.18 \\
\hline$R X R A$ & 23.75 & 1.97 & -3.07 & 0.993 & 2.12 \\
\hline SCAP & 27.27 & 4.18 & -3.03 & 0.981 & 2.14 \\
\hline$S C D$ & 17.25 & -5.10 & -3.11 & 0.993 & 2.10 \\
\hline SREBF1 & 28.30 & 6.51 & -2.66 & 0.981 & 2.38 \\
\hline THRSP & 30.56 & 7.58 & -2.66 & 0.984 & 2.38 \\
\hline$X D H$ & 18.10 & -5.04 & -3.17 & 0.998 & 2.07 \\
\hline \multicolumn{6}{|c|}{ Adipose Tissue } \\
\hline ACACA & 21.01 & -1.53 & -3.16 & 0.996 & 2.07 \\
\hline ACSS2 & 25.33 & 2.44 & -2.97 & 0.990 & 2.17 \\
\hline$A D F P$ & 24.99 & 2.28 & -3.12 & 0.997 & 2.09 \\
\hline DGAT2 & 25.95 & 3.17 & -2.94 & 0.968 & 2.19 \\
\hline ELOVL6 & 19.94 & -2.25 & -3.41 & 0.988 & 1.96 \\
\hline FABP4 & 16.42 & -6.30 & -3.30 & 0.997 & 2.01 \\
\hline FASN & 24.44 & 1.82 & -2.94 & 0.979 & 2.19 \\
\hline INSIG1 & 22.92 & 0.34 & -3.29 & 0.995 & 2.01 \\
\hline LPIN1 & 24.05 & 1.31 & -3.14 & 0.990 & 2.08 \\
\hline$L P L$ & 19.05 & -4.10 & -3.01 & 0.991 & 2.15 \\
\hline MED1 & 25.48 & 3.77 & -3.59 & 0.994 & 1.90 \\
\hline$P P A R G$ & 22.67 & -0.68 & -2.96 & 0.983 & 2.18 \\
\hline$R X R A$ & 22.89 & 1.14 & -3.07 & 0.993 & 2.12 \\
\hline SCAP & 26.67 & 4.09 & -3.03 & 0.981 & 2.14 \\
\hline$S C D$ & 17.69 & -5.39 & -3.11 & 0.993 & 2.10 \\
\hline SREBF1 & 27.77 & 5.94 & -2.66 & 0.981 & 2.38 \\
\hline THRSP & 21.25 & -1.06 & -2.66 & 0.984 & 2.38 \\
\hline
\end{tabular}


Table S5 (Continued).

\begin{tabular}{lccccc}
\hline Gene & Median Ct & Median $\Delta \mathbf{C t}^{\mathbf{2}}$ & Slope $^{\mathbf{3}}$ & $\mathbf{( R}^{\mathbf{2}} \mathbf{4}^{\mathbf{2}}$ & Efficiency $^{\mathbf{6}}$ \\
\hline Liver & & & & & \\
ACOX1 & 27.79 & 2.95 & -3.12 & 0.988 & 2.09 \\
APOB & 20.03 & -4.60 & -3.28 & 0.997 & 2.02 \\
CPT1A & 28.44 & 3.82 & -2.68 & 0.988 & 2.36 \\
HMGCS2 & 23.92 & -0.98 & -2.92 & 0.997 & 2.20 \\
PPARA & 28.09 & 3.19 & -2.83 & 0.989 & 2.25 \\
RXRA & 24.10 & -0.89 & -3.37 & 0.991 & 1.98 \\
\hline
\end{tabular}

${ }^{1}$ The median is calculated considering all ewes.

${ }^{2}$ The median of $\Delta \mathrm{Ct}$ is calculated as [Ct gene - geometrical mean of $\mathrm{Ct}$ internal controls] for each ewe.

${ }^{3}$ Slope of the standard curve.

${ }^{4} \mathrm{R}^{2}$ stands for the coefficient of determination of the standard curve.

${ }^{5}$ Efficiency is calculated as $\left[10^{(-1 / \text { Slope })}\right]$. 


\section{REFERENCES}

Bionaz, M. and J. J. Loor. 2007. Identification of reference genes for quantitative realtime PCR in the bovine mammary gland during the lactation cycle. Physiol Genomics 29:312-9.

Bionaz, M. and J. J. Loor. 2008a. Gene networks driving bovine milk fat synthesis during the lactation cycle. BMC Genomics 9:366.

Bionaz, M. and J. J. Loor. 2008b. ACSL1, AGPAT6, FABP3, LPIN1, and SLC27A6 are the most abundant isoforms in bovine mammary tissue and their expression is affected by stage of lactation. J. Nutr. 138:1019-1024.

Invernizzi, G., B. J. Thering, M. A. McGuire, G. Savoini and J. J. Loor. 2010. Sustained upregulation of stearoyl-CoA desaturase in bovine mammary tissue with contrasting changes in milk fat synthesis and lipogenic gene networks caused by lipid supplements. Funct. Integr. Genomics 10:561-575.

Ji, P., J. S. Osorio, J. K. Drackley and J. J. Loor. 2012. Overfeeding a moderate energy diet prepartum does not impair bovine subcutaneous adipose tissue insulin signal transduction and induces marked changes in peripartal gene network expression. J. Dairy Sci. 95:4333-4351.

Kadegowda, A. K. G., M. Bionaz, B. Thering, L. S. Piperova, R. A. Erdman and J. J. Loor. 2009. Identification of internal control genes for quantitative polymerase chain reaction in mammary tissue of lactating cows receiving lipid supplements. J. Dairy Sci. 92:2007-2019.

Loor, J., H. Dann, R. Everts, R. Oliveira, C. Green, N. Guretzky, S. Rodriguez-Zas, H. Lewin and J. Drackley. 2005. Temporal gene expression profiling of liver from periparturient dairy cows reveals complex adaptive mechanisms in hepatic function. Physiol. Genomics 23:217-226. 
Loor, J. J., R. E. Everts, M. Bionaz, H. M. Dann, D. E. Morin, R. Oliveira, S. L. Rodriguez-Zas, J. K. Drackley and H. A. Lewin. 2007. Nutrition-induced ketosis alters metabolic and signaling gene networks in liver of periparturient dairy cows. Physiol. Genomics 32:105-116.

Naeem, A., J. K. Drackley, J. Stamey and J. J. Loor. 2012. Role of metabolic and cellular proliferation genes in ruminal development in response to enhanced plane of nutrition in neonatal Holstein calves. J. Dairy Sci. 95:1807-1820.

Schmitt, E., M. A. Ballou, M. N. Correa, E. J. DePeters, J. K. Drackley and J. J. Loor. 2011. Dietary lipid during the transition period to manipulate subcutaneous adipose tissue peroxisome proliferator-activated receptor- $\gamma$ co-regulator and target gene expression. J. Dairy Sci. 94:5913-25.

Thering, B. J., D. E. Graugnard, P. Piantoni and J. J. Loor. 2009. Adipose tissue lipogenic gene networks due to lipid feeding and milk fat depression in lactating cows. J. Dairy Sci. 92:4290-4300.

Zang, R., J. Bai, H. Xu, L. Zhang, J. Yang, L. Yang, J. Lu and J. Wu. 2011. Selection of suitable reference genes for real-time quantitative PCR studies in Lanzhou fattailed sheep (Ovis aries). Asian J. Anim. Vet. Adv. 6:789-804. 